\title{
THE ROLE OF NATURAL RESOURCES IN THE ECOTOURISM DEVELOPMENT - RESIDENTS' PERCEPTIONS IN SUBOTICA (NORTHERN SERBIA)
}

\author{
Aleksandra VUJKO ${ }^{\mathrm{a}, \mathrm{b}}$, Marko D. PETROVIĆb, ${ }^{\mathrm{c}}$, Danica GOSTOVIĆa \\ Milan RADOVANOVIĆ ${ }^{\text {b, }}$, Darko VUKOVIĆ ${ }^{\text {b,d }}$ \\ ${ }^{a}$ Novi Sad Business School, Vladimira Perića Valtera 4, Novi Sad 21000, Serbia, \\ aleksandravujko@yahoo.com; danicagostovic@yahoo.com \\ ${ }^{\mathrm{b}}$ South Ural State University, Institute of Sports, Tourism and Service, 76 Lenin Ave., Chelyabinsk \\ 454080, Russia \\ c Geographical Institute "Jovan Cvijić" SASA, Djure Jakšića 9, Belgrade 11000, Serbia, \\ m.petrovic@gi.sanu.ac.rs; m.radovanovic@gi.sanu.ac.rs; d.vukovic@gi.sanu.ac.rs \\ ${ }^{d}$ National Research University Higher School of Economics, St. Petersburg School of Economics and \\ Management, Department for Finance, Kantemirovskaya St. 3A, Office 331, Sankt Petersburg 194100, \\ Russia \\ * Correspondence to: m.petrovic@gi.sanu.ac.rs
}

Cite this article: Vujko, A., Petrović, M.D., Gostović, D., Radovanović, M., Vuković, D. (2018). The Role of Natural Resources in the Ecotourism Development - Residents' Perceptions in Subotica (Northern Serbia). Deturope, 10(2), 112-123.

\begin{abstract}
Regardless of their type and structure, natural resources represent the basis for industrial and economic development of every country. The aim of this study is to determine and display the natural potential in the territory of the City of Subotica (Vojvodina Province in Northern Serbia), on the basis of four protected natural areas. These areas are: Palić Nature Park, Ludaško jezero Special Nature Reserve, Selevenjske pustare Special Nature Reserve and Subotička peščara Protected Landscape of Exceptional Distinction. All listed areas represent the main aspects for ecotourism development in this part of the country, so one of the aims of the research is to identify key stakeholders that should be involved in proper developing of this form of tourism. When preforming this study, survey research techniques were used. Respondents were Subotica's residents, who were asked to rate the state of the environment in these surroundings, as well as to give their opinions about the possibilities for the development of ecotourism. Based on the analysis of the dependent and independent variables, it was concluded that the residents are generally satisfied with the conditions of the environment, they also consider that the development of this form of tourism would raise the awareness of locals about the importance of preserving these protected areas. The result may be significant when launching a new tourism product, while preserving the protected areas and adapting for future visitors' needs.
\end{abstract}

Keywords: natural resources, industrial and economic development, protected areas, ecotourism, Subotica

\section{INTRODUCTION}

The term "sustainability" has many meanings and contents and relying on the views of the authors who dealt recently with this topic (Bacsi, 2017; Jojić Glavonjić, Todorić, Doljak, \& Golubović, 2017; Vujko, Plavša, Petrović, Radovanović, \& Gajić, 2017). We conclude that 
for a particular community, sustainable is what enables lasting economic growth and development, what is socially acceptable, harmonizes the relationship and measure of economic and social development according to ecological capacities and is politically acceptable (it can be subject to agreement in official institutions). Tourism, looking through the prism of sustainability, is a concept based on undertaking activities that enable appropriate financial and economic arrangements, new technological and technical solutions, promotion and education, a new way of public communication and interaction, with an emphasis on openness, cooperation and transparency and new coalitions for sustainable development (Marković, Perić, Mijatov, Doljak, \& Žolna, 2017; Petrović, Blešić, Vujko, \& Gajić, 2017). Between several approaches to sustainable tourism (Bacsi, 2017; Petrović, Vujko, Gajić, Vuković, Radovanović, Jovanović \& Vuković, 2018), there is some approaches that outline its relationship with ecotourism (Ocampo, Ebisa, Ombe \& Esco, 2018), following the definition set by Blangy and Wood (1993; p. 32), according which the ecotourism is "responsible travel to natural areas that conserves the environment and sustains the well-being of local people".

Often the existence of certain natural resources has a crucial impact on the development of the local community, giving it a certain identity, which continuously allows for a high-quality tourist interpretation of these natural resources that the observed area gravitates to, in this case, the City of Subotica. Modern trends emphasize the development of specific forms of tourism, and ecotourism is one of them. Urban areas having natural resources suitable for the development of ecotourism in their immediate surroundings represent potentials for development. The City of Subotica is the northernmost city in the Republic of Serbia and the second largest in the Vojvodina Province. According to the 2011 census, the City of Subotica has a population of 97.910 inhabitants while the urban area of Subotica (with adjacent urban settlement of Palić included) has 105.681 inhabitants. It is located $10 \mathrm{~km}$ from the Serbian border with Hungary and covers an area of $1,008 \mathrm{~km} 2$, includes the territories of the Subotica town and 18 surrounding villages. The relief of Subotica and its surroundings was created predominantly by wind (aeolian erosion and accumulation), which created numerous dunes and interdune depressions mostly in the northwest-southeast direction (Kovačević, 2006). The city's surroundings have four protected natural areas that are specific for their numerous protected plant and animal species. Subotička peščara is located just along the border between Serbia and Hungary (Fig. 1). 
Figure 1 Observed area

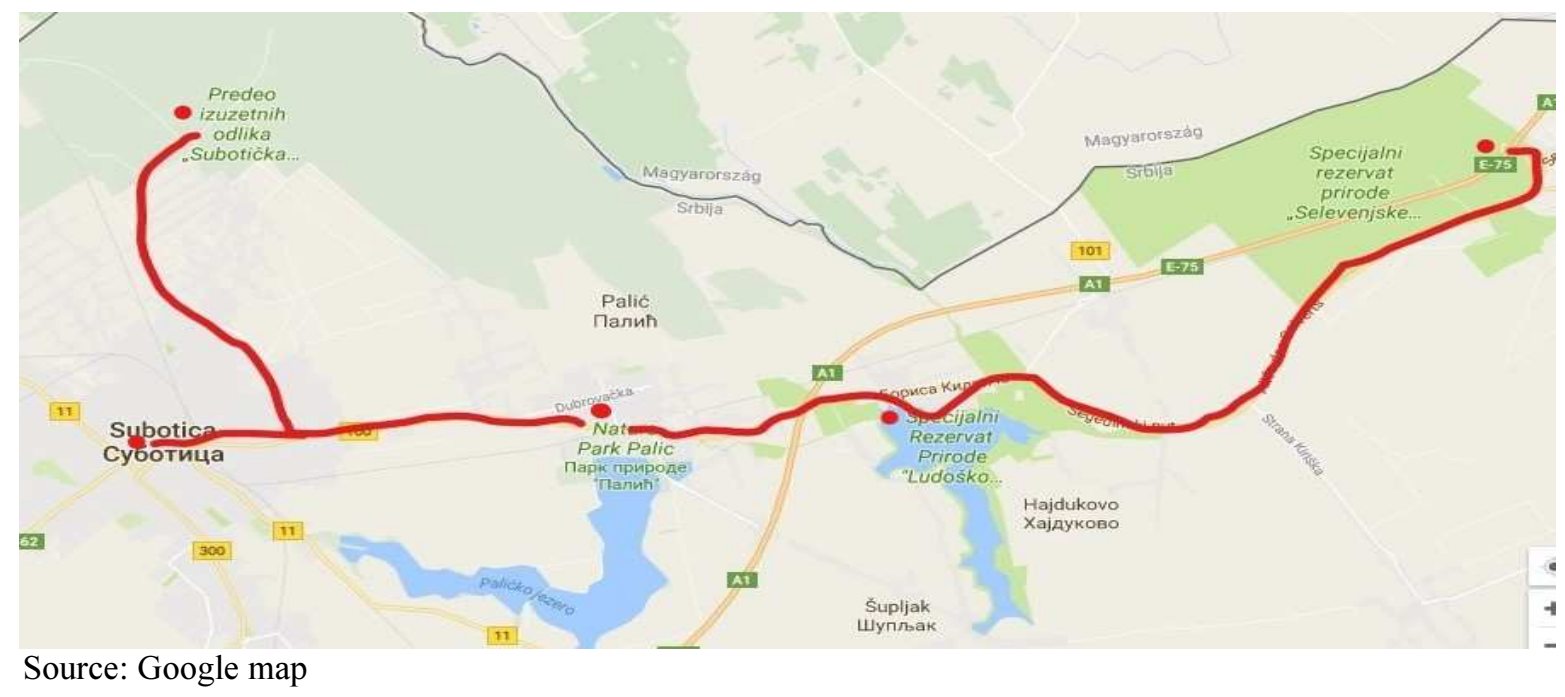

In geomorphologic terms, this area is homogeneous and has a plain character. It extends to the section of the big plateau, which crosses from Hungary to our territory to the Kula-Sombor line. Moving further to the border, the "Selevenjske pustare" Special Nature Reserve is building on Subotička peščara. Selevenjske pustare is located between the town of Bački Vinogradi and Horgoš, and one part of it is part of the Municipality of Kanjiža. This protected area is characterized by the fact that for some species, it is the only habitat in our country or is one of the few existing sites (Maravić, 1997). The small town of Palić, as well as the Palić Nature Park, are $7 \mathrm{~km}$ from the center of Subotica. Palić is a very important tourist and recreational center of this area, while the Nature Park is an area of international importance for birds (IBA) and plants (IPA), and is part of the EMERALD network of areas of international importance for the conservation of biological diversity. In addition to this natural reserve, in the villages of Šupljak, Hajdukovo and Nosa, there is Ludaško jezero (Ludaš Lake), which is also located on the eastern European migration path of birds. Ludaško jezero is significant as one of the rare habitats for some of the rare and endangered birds, and it is also known as a place for many other endangered plant and animal species.

The subject of this paper is to present a resource basis for the development of ecotourism in protected natural areas, and to improve the tourism offer of the City of Subotica. The aim of the paper is to study protected areas and bring them closer to both tourists and the local population. The task is to popularize these protected areas, based on valorization and zoning, as well as with the survey carried out on a sample of 328 respondents, in order to enable their higher attendance, better understanding and use. 


\section{METHODOLOGY}

For the purposes of this study, the filed research was conducted, involving four protected natural areas of Subotica (Palić, Ludaško jezero, Selevenjske pustare and Subotička peščara), and assistance in gathering data was given by Robert Čordaš, $\mathrm{PhD}$, an expert in the field of environment protection. In addition to interview for research purposes, a survey was conducted during 2017 (from March to September) among 400 respondents, residents of the City of Subotica, with the aim of gaining insight into their knowledge of protected areas as well as the views on the economic aspects of ecotourism. Total number of 328 respondents filled questionnaire correctly. In order to obtain better results, SWOT analysis of existing protected natural areas has been done, as well as valorization of the space by qualitativequantitative method. This method represents one of the more widely used methods because it provides great freedom in research and estimates and is based on six indicators: accessibility of resources, tourist equipment, ambience, resource specificity, importance of resources and artistic value. Estimates i.e. set elements of tourist valorization, during the affirmation of resources, ranged 1-5 and marked the size of the contraction zone, in fact the significance of the destination itself. The meanings of numbers were as follows: 1 - number one denoted inadequate quality, 2 - quality that satisfies the local tourist significance, 3 - a good quality of resources with a regional significance, 4 - very good quality with a wider regional (national significance) and 5 - excellent quality of resources of international importance (Čomić, \& Pjevač, 1997; Vujko, \& Plavša, 2014). Valorization of natural sites is more complex than the valorization of anthropogenic tourist values because they differ in time and way of their origin, their elements, genesis, as well as that they can simultaneously satisfy more tourist needs (trips, sports, recreation, hunting, fishing, nautical, education, health needs). During the development of this work, zoning of protected natural areas was also made, on the basis of which it is possible to connect them for the purposes of realization of tourist tours. The connection of these protected areas is possible due to their immediate proximity, which, with the development of pedestrian and cycling routes as well as adequate signalization, will enable easier implementation of the tourists as well as the possibility for tourists to independently visit these areas. In this paper, a presentation of the traffic of tourists in the period from 2012 to 2016 was made. The data came from the database of the Republic Statistical Office from 2017. 


\section{RESULTS AND DISCUSSION}

Subotica and its surroundings have natural and anthropogenic tourist potentials which can attract more visitors. Four protected natural areas are particularly emphasized, which are considered to have the power to attract a much larger number of tourists by arranging and investing in them. In order to gain a better insight into the state of the environment in the City of Subotica, SWOT analysis (Table 1) was made, which presents the internal advantages and disadvantages, as well as the chances and threats from the environment. The main advantage of Subotica as a tourist destination is the proximity to the border with Hungary, the proximity of the E 75 highway as well as good connectivity with all the roads and places in the surrounding area. What is the main topic of this work and what is needed in the future to pay even greater attention is well-preserved natural resources, plains, forests, sands, lakes, loess plateaus, as well as international protection statuses. It is also important to emphasize the preserved original material and immaterial heritage of local cultures as well as multiethnicity and tolerant mentality. Especially attractive for tourists in this area is precisely a mixture of different nationalities, cultures, traditions and gastronomy, which also needs to put special emphasis on further development of tourism. The main disadvantage of this area is poor infrastructure, which leads to the fact that tourists are not able to move independently from the city center. The second disadvantage is that there is no adequate destination management on the basis of which Subotica as a tourist destination would be more recognizable in the wider tourist market. The lack is also insufficient cooperation between the municipalities, tourist organizations, economic organizations and the local population. What is possible to present as important chances for further development of tourism is certainly the development and placement of new forms of tourism, specifically in this case ecotourism, as well as the involvement of the local community, which enables new jobs and a better standard of living. All these should be accompanied by adequate marketing activities in order to make new tourist products more visible to current and potential tourists. The main threats are the lack of financial support, as well as domestic and foreign investments in sustainable tourism, high unemployment and a growing trend of emigration of young and educated people. In addition, the main threat to the development of ecotourism is the devastation of the natural areas due to the development of the economy. The cause of the devastation of natural areas is precisely the insufficient education of the local population on the importance of protected areas. 
Table 1 SWOT analysis of surrounding natural resources of the City of Subotica

\begin{tabular}{|c|c|}
\hline STRENGTHS & WEAKNESSES \\
\hline $\begin{array}{l}\text { - } \text { Favorable geographical position } \\
\text { - Connectivity with the surrounding areas } \\
\text { - Well-preserved diverse nature (plains, } \\
\text { forests, sands, lakes, loess plateaus) } \\
\text { - International protection statuses } \\
\text { - The original and preserved material and } \\
\text { immaterial heritage of the local } \\
\text { population } \\
\text { - Multiethnicity and tolerant mentality }\end{array}$ & 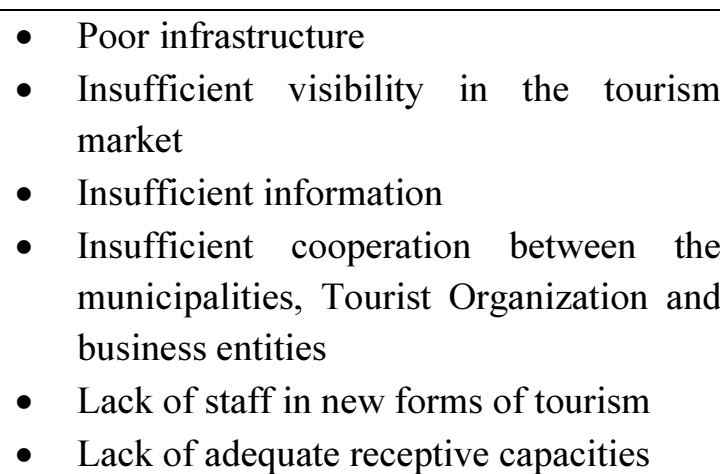 \\
\hline OPORTUNITIES & $\begin{array}{c}\text { THREATS } \\
\end{array}$ \\
\hline $\begin{array}{l}\text { - Resources for the development of } \\
\text { ecotourism } \\
\text { - Designing a new tourist offer } \\
\text { - Incorporating a local community enabling } \\
\text { new jobs and a better standard of living } \\
\text { - Improving marketing activities } \\
\text { - Organization of educational lectures, } \\
\text { seminars, fairs }\end{array}$ & $\begin{array}{l}\text { - Lack of financial support } \\
\text { - Devastation of natural areas due to the } \\
\text { development of economy and tourism } \\
\text { - Lack of domestic and foreign investments } \\
\text { in sustainable tourism and ecotourism } \\
\text { - Economic crisis } \\
\text { - High level of unemployment and the } \\
\text { trend of emigration of young and } \\
\text { educated people }\end{array}$ \\
\hline
\end{tabular}

Source: Authors' research

One of the ways in which the mentioned area could be activated is certainly tourist valorization. Based on valorization, an estimate was made of the value of tourist attractions of this area through which tourists can meet their needs. Based on the valorization (Table 2) it is possible to notice that the Nature Park Palić was rated very high. The Special Nature Reserve "Ludaško jezero" stands out immediately after this protected area. This reserve has special significance for its specificity, due to the special and rare species of birds and plants, due to the existence of a visitor center and ornithological station. The next reservation, which is distinguished by its specificity, is the Special Nature Reserve "Selevenjske pustare". Although there is no tourist equipment in this area, it is certainly significant for the rare and endangered plant and bird species that are nesting here. Less accessible and equipped with respect to the rest is the Landscape of Exceptional Features "Subotička peščara", but it is significant for specific plant and animal world. 
Table 2 Valorization of natural areas of the City of Subotica

\begin{tabular}{|c|c|c|c|c|c|c|}
\hline $\begin{array}{c}\text { Protected } \\
\text { goods }\end{array}$ & $\begin{array}{c}\text { Accessibility } \\
\text { of the } \\
\text { resource }\end{array}$ & $\begin{array}{c}\text { Tourist } \\
\text { equipment }\end{array}$ & Ambiance & $\begin{array}{c}\text { Specificity } \\
\text { of the } \\
\text { resource }\end{array}$ & $\begin{array}{c}\text { The } \\
\text { importance } \\
\text { of the } \\
\text { resource }\end{array}$ & $\begin{array}{c}\text { Artistic } \\
\text { value }\end{array}$ \\
\hline $\begin{array}{c}\text { Nature Park } \\
\text { Palić }\end{array}$ & 4.5 & 4 & 5 & 4 & 4.5 & 5 \\
\hline $\begin{array}{c}\text { Special Nature } \\
\text { Reserve } \\
\text { "Ludaško } \\
\text { jezero" }\end{array}$ & 4.5 & 4.5 & 3.5 & 5 & 5 & - \\
\hline $\begin{array}{c}\text { Special Nature } \\
\text { Reserve } \\
\text { "Selevenjske } \\
\text { pustare" }\end{array}$ & 4 & 3 & 3.5 & 5 & 5 & - \\
\hline $\begin{array}{c}\text { Landscape of } \\
\text { Exceptional } \\
\text { Features } \\
\text { "Subotička } \\
\text { peščara" }\end{array}$ & 3 & 3 & 3 & 4 & & \\
\hline
\end{tabular}

Source: Authors' research

During the development of this work, zoning of protected natural areas was also made, on the basis of which it is possible to connect them for the purposes of realization of tourist tours. The starting point of this visit is the Nature Park Palić, and except the park, there would be a possibility to visit the lake and other sights of the area. After that, a tour of the Special Nature Reserve "Ludaško jezero" would be carried out, which is about $7 \mathrm{~km}$ away from Palić. Educational walks, lectures on protected and rare species of birds, as well as observation of them, would be held here. Tourists would go further to the Special Nature Reserve "Selevenjske pustare", which is located $19 \mathrm{~km}$ from Ludaško jezero, where it is also possible to hold a short educational lecture and walk through the entire reservation along the marked paths. After that, along the border line with Hungary it is possible to reach the Landscape of exceptional features "Subotička peščara", which is $25 \mathrm{~km}$ away, where the skilled person would explain the origin of sands, the significance of afforestation.

Based on data from the Statistical Office of the Republic of Serbia in 2017 (Table 3) on tourist traffic in Subotica, it is possible to notice that 2016 was the year when the traffic of tourists was the highest in the observed period. Also, the number of foreign tourist overnight stays in Subotica in 2016 exceeded the number of overnight stays of domestic guests. 
Table 3 Arrivals and overnights of domestic and foreign tourists in the City of Subotica (2012-2016)

\begin{tabular}{|l|r|r|r|r|r|r|}
\hline \multirow{2}{*}{ Year } & \multicolumn{3}{|c|}{ Arrivals } & \multicolumn{3}{c|}{ Nights } \\
\cline { 2 - 7 } & Domestic & Foreign & Total & Domestic & Foreign & Total \\
\hline 2012 & 24,076 & 13,855 & 37,931 & 38,078 & 29,787 & 67,865 \\
\hline 2013 & 28,201 & 18,983 & 47,184 & 46,537 & 38,575 & 85,112 \\
\hline 2014 & 34,884 & 21,842 & 56,726 & 52,534 & 42,081 & 94,615 \\
\hline 2015 & 35,677 & 24,414 & 60,091 & 54,970 & 54,970 & 109,101 \\
\hline 2016 & 37,845 & 24,977 & 62,822 & 59,112 & 55,011 & 114,123 \\
\hline
\end{tabular}

Source: Statistical Office of the Republic of Serbia, 2017

The survey involved 328 respondents, of whom 172 were male respondents and 156 female respondents. By looking at the Table 4, it can be concluded that the residents of Subotica are very interested in spending their free time in nature as places for rest and relaxation.

Table 4 Opinion of the respondents about interest of residents of Subotica in ecotourism

\begin{tabular}{|c|c|c|c|c|c|c|}
\hline & \multicolumn{2}{|c|}{$\begin{array}{l}\text { Opinion of the respondents about } \\
\text { interest in natural resources in } \\
\text { Subotica }\end{array}$} & \multirow{2}{*}{ Total } \\
\hline & & & & Yes & I don't know & \\
\hline Gender & $f$ & $\%$ & & & & \\
\hline \multirow{2}{*}{ Male } & \multirow[t]{2}{*}{172} & \multirow{2}{*}{52.4} & Number & 172 & 0 & 172 \\
\hline & & & $\%$ & $52.4 \%$ & $0 \%$ & $52.4 \%$ \\
\hline \multirow[t]{2}{*}{ Female } & \multirow[t]{2}{*}{156} & \multirow[t]{2}{*}{47.6} & Number & 151 & 5 & 156 \\
\hline & & & $\%$ & $46.0 \%$ & $1.5 \%$ & $47.6 \%$ \\
\hline \multirow[t]{2}{*}{ Total } & \multirow[t]{2}{*}{328} & \multirow[t]{2}{*}{100} & 47.6 & 323 & 5 & 328 \\
\hline & & & $\%$ & $98.5 \%$ & $1.5 \%$ & $100 \%$ \\
\hline
\end{tabular}

Source: Authors' research

Table 5 Opinion of the respondents on the benefits of the development of ecotourism

\begin{tabular}{|c|c|c|c|c|c|}
\hline \multirow{2}{*}{\multicolumn{3}{|c|}{$\begin{array}{l}\text { Answers in relation to gender of } \\
\text { respondents }\end{array}$}} & \multicolumn{2}{|c|}{$\begin{array}{l}\text { Opinion of the respondents } \\
\text { about benefits of investing in } \\
\text { natural resources in the area }\end{array}$} & \multirow{3}{*}{$\begin{array}{l}\text { Total } \\
172 \\
\end{array}$} \\
\hline & & & \multirow{2}{*}{$\begin{array}{l}\text { Yes } \\
167\end{array}$} & \multirow{2}{*}{$\frac{\text { I don't know }}{5}$} & \\
\hline \multirow[t]{4}{*}{ Gender } & \multirow[t]{2}{*}{ Male } & Number & & & \\
\hline & & $\%$ & $50.9 \%$ & $1.5 \%$ & $52.4 \%$ \\
\hline & \multirow[t]{2}{*}{ Female } & Number & 148 & 8 & 156 \\
\hline & & $\%$ & $45.1 \%$ & $2.4 \%$ & $47.6 \%$ \\
\hline \multirow{2}{*}{\multicolumn{2}{|c|}{ Total }} & Number & 315 & 13 & 328 \\
\hline & & $\%$ & $\%$ & $4.0 \%$ & $100 \%$ \\
\hline
\end{tabular}

Source: Authors' research

The data from the Table 5 indicate a high level of awareness of the population that is beneficial to the city itself, if ecotourism in natural resources would develop. The Table 6 highlights which are, in the opinion of the population, the main benefits and advantages. First of all, it can be seen that as many as $91.5 \%$ of the population consider that the biggest 
advantage of the development of ecotourism is the creation of new jobs, which directly points to the economic aspect of tourism development. Some scientists believe that "job creation" is one of the most important economic indicators that benefits tourism development (Gaddefors, 2005; Getz, \& Carlsen, 2005; Vujko, Petrović, Dragosavac, \& Gajić, 2016; Nagy, Káposzta, $\&$ Meta, 2017). Tourist traffic which can be seen in the Table 3 shows the existence of potential for development, as well as the importance of natural resources in terms of one of the main motivators that drive tourists to leave the place of permanent residence.

Table 6 Opinion of the respondents on the benefits of connection between natural resources and the city

\begin{tabular}{|c|c|c|c|c|c|}
\hline \multirow{2}{*}{\multicolumn{3}{|c|}{ Answers in relation to gender of respondents }} & \multicolumn{2}{|c|}{ Gender } & \multirow{3}{*}{$\begin{array}{l}\text { Total } \\
300\end{array}$} \\
\hline & & & Male & Female & \\
\hline \multirow{14}{*}{$\begin{array}{l}\text { Opinion of the respondents } \\
\text { about benefits }\end{array}$} & \multirow[t]{2}{*}{ New jobs } & Number & 162 & 138 & \\
\hline & & $\%$ & $49.4 \%$ & $42.1 \%$ & $91.5 \%$ \\
\hline & \multirow{2}{*}{$\begin{array}{l}\text { More investment in } \\
\text { infrastructure }\end{array}$} & Number & 0 & 7 & 7 \\
\hline & & $\%$ & $0 \%$ & $2.1 \%$ & $2.1 \%$ \\
\hline & \multirow{2}{*}{$\begin{array}{l}\text { The young would stay in } \\
\text { Subotica }\end{array}$} & Number & 0 & 4 & 4 \\
\hline & & $\%$ & $0 \%$ & $1.2 \%$ & $1.2 \%$ \\
\hline & \multirow[t]{2}{*}{ The city would increase } & Number & 3 & 3 & 6 \\
\hline & & $\%$ & $0.9 \%$ & $0.9 \%$ & $1.8 \%$ \\
\hline & \multirow{2}{*}{$\begin{array}{l}\text { The inhabitants would have } \\
\text { more "health trails" }\end{array}$} & Number & 2 & 3 & 5 \\
\hline & & $\%$ & $0.6 \%$ & $0.9 \%$ & $1.5 \%$ \\
\hline & \multirow{2}{*}{$\begin{array}{l}\text { The inhabitants would have a } \\
\text { place to swim }\end{array}$} & Number & 2 & 1 & 3 \\
\hline & & $\%$ & $0.6 \%$ & $0.3 \%$ & $0.9 \%$ \\
\hline & \multirow[t]{2}{*}{ Something else } & Number & 3 & 0 & 3 \\
\hline & & $\%$ & $0.9 \%$ & $0 \%$ & $0.9 \%$ \\
\hline \multirow{2}{*}{\multicolumn{2}{|c|}{ Total }} & Number & Number & 156 & 328 \\
\hline & & $\%$ & $\%$ & $47.6 \%$ & $100 \%$ \\
\hline
\end{tabular}

Source: Authors' research

Ecotourism would contribute to the improvement of protected areas and ensure their better conservation and protection levels. The ultimate goal is to ensure the long-term competitive advantage of the destination on the tourism market.

\section{CONCLUSION}

Many economies of the world achieve significant market positions owing to the existence of natural resources. In recent years, with the rapid development of technology, a stressful and fast-moving lifestyle, there is an increasingly frequent trend of escapism in people, staying in nature and a healthy lifestyle. The City of Subotica, as a tourist destination, has so far been engaged in the development of many types of tourism (urban, event, cultural-historical, sports-recreational, wine tourism, etc.), while protected nature reserves have remained 
neglected. It is precisely the greatest potential for further tourism development in this destination that lies in protected natural areas. Along with the planned development of ecotourism, these areas would be preserved from devastation and destruction, environmental improvement would be achieved, the local population would gain insight into their overall benefit, there would be links between different entrepreneurs, government and nongovernmental organizations and the local community. In order to facilitate the efficient development of this type of tourism, it is necessary to include a team of experts in its implementation and in the formation of projects, as well as to give young people the opportunity to volunteer their contribution to their community. Based on the developed projects, there will be an opportunity to compete for the various funds offered by the European Union, as well as for attracting foreign investments and establishing cross-border cooperation with countries in the region.

From all these it can be concluded that the City of Subotica has great potential for development of ecotourism, which would increase the tourist offer on this destination. This is a type of individual tourism or small-scale tourism, as it is mostly about groups of up to 25 people. The advantage of this type of tourism is that there is no age restriction for eco-tourists. Ecotourism can be adapted for all ages and profiles (children, young people, adults and retirees, biologists, ecologists, scientists, etc.). What certainly contributes to the development of this form of tourism is that the local population sees the importance and benefits of this form of tourism. The greatest benefit of eco-tourism development is definitely new job creation. In this way, a responsible attitude of local communities towards protected areas in their environment would be achieved. Campsites that could be the backbone of tourism development should precisely be developed in these areas, and various types of workshops as well as nature schools for children will be organized in order to educate them on the importance of the environment and protected areas. Other activities of the camps would be sports and recreation, cycling, educational walks, bird watching. The mission of this form of tourism would primarily be the expansion of the business network and the establishment of cooperation with all relevant subjects of the economic and social life that are important to improve tourism in the City of Subotica and for planning the positioning in the market. It is necessary to enable the connection of key stakeholders who will work together on the formation and implementation of this tourist product. It is necessary to establish constant information and marketing support, publication of printed publications and the creation of a website. The most important is cooperation with the Tourist Organization of the city of 
Subotica, which will actively present this form of tourism and direct interested tourists to engage in ecotourism activities.

\section{Acknowledgments}

The research was supported by Ministry of Education, Science and Technological Development, Republic of Serbia (Grant III 47007) and by the Act 211 Government of the Russian Federation, contract № 02.A03.21.0011.

\section{REFERENCES}

Bacsi, Z. (2017). Tourism and diversity. Deturope - The Central European Journal of Regional Development and Tourism, 9(2), 25-57.

Blangy, S., \& Wood, M.E., (1993). Developing and implementing ecotourism guidelines for wildlands and neighboring communities, In: Lindberg, K., Hawkins, D.E. (Eds.), Ecotourism: a Guide for Planners and Managers, Vermont, North Bennington, pp. 3254.

Čomić, D., \& Pjevač, N. (1997). Turistička geografija. Belgrade: Savezni centar za unapredjenje hotelijerstva i ugostiteljstva.

Gaddefors, J. (2005). Creating context entrepreneurial opportunities in a consumer market setting. Journal of Enterprising Culture, 13(3), 199-224.

Getz, D., \& Carlsen, J. (2005). Family business in tourism: State of the art. Annals of Tourism Research, 32(1), 237-258.

Jojić Glavonjić, T., Todorić, J., Doljak, D., \& Golubović, N. (2017). Analysis of Tourist Motifs in the Function of Development of Cultural Tourism in the Settlements Surrounded by Protected Natural Resources. Journal of the Geographical Institute "Jovan Cvijič" SASA, 67(3), 333-340.

Kovačević, T. (2006). Opština Subotica. Novi Sad: Univerzitet u Novom Sadu, Prirodnomatematički fakultet, Departman za geografiju, turizam i hotelijerstvo.

Maravić, V. (1997). Prirodne turističke vrednosti kao komponenta razvoja turizma opštine Subotica. Novi Sad: Univerzitet u Novom Sadu, Prirodno-matematički fakultet, Departman za geografiju, turizam i hotelijerstvo.

Marković, S., Perić, M., Mijatov, M., Doljak, D., \& Žolna, M. (2017). Application of Tourist Function Indicators in Tourism Development. Journal of the Geographical Institute "Jovan Cvijic" SASA, 67(2), 163-178.

Nagy, H., Káposzta, J., \& Meta, B. (2017). The potentials of rural tourism in developing rural areas in Albania. Deturope - The Central European Journal of Regional Development and Tourism, 9(3), 188-206.

Ocampo, L., Ebisa, J.A., Ombe, J., \& Escoto, M.G. (2018). Sustainable ecotourism indicators with fuzzy Delphi method - A Philippine perspective Short communication. Ecological Indicators, 93, 874-888

Petrović, M.D., Blešić, I., Vujko, A., \& Gajić, T. (2017). The role of agritourism impact on local community in a transitional society: a report from Serbia. Transylvanian Review of Administrative Sciences, 50, 146-163.

Petrović, M.D., Vujko, A., Gajić, T., Vuković, D., Radovanović, M., Jovanović, J., \& Vuković, N. (2018). Tourism as an Approach to Sustainable Rural Development in Post-Socialist Countries: A Comparative Study of Serbia and Slovenia. Sustainability, 10(54), 2-14. 
Vujko, A., \& Plavša, J. (2014). Evaluation of National Park Fruška Gora (Serbia) for sport and recreational tourism. Acta geographica Slovenica, 54(2), 321-334.

Vujko, A., Petrović, M.D., Dragosavac, M., \& Gajić, T. (2016). Differences and similarities among rural tourism in Slovenia and Serbia - perceptions of local tourism workers. Ekonomika poljoprivrede, 4, 1459-1469.

Vujko, A., Plavša J., Petrović, M.D., Radovanović, M., \& Gajić, T. (2017). Modeling of tourism carrying capacity in the national parks - Fruška gora (Serbia) case study. Open Geosciences, 9, 61-72. 